\title{
ODUS: Filosofia Africana para uma metodologia afrorreferenciada
}

\author{
ODUS: African Philosophy for an afro-referenced methodology
}

\author{
Adilbênia Freire Machado*
}

\begin{abstract}
Resumo: O presente artigo apresenta a metodologia filosófica, que também é conteúdo, dos Odus. Trata-se de uma metodologia afrorreferenciada demarcada por nossa origem, nossa ancestralidade, nossos caminhos / experiências / vivências. Alimentaremos, aqui, um diálogo formativo desde as culturas, os modos de ser / estar no mundo, as filosofias e saberes africanos e afrodescendentes. Busca-se delinear um pensamento plural, diverso, numa perspectiva horizontal, circular, que compreende a universalidade desde um lugar, desde nosso próprio chão, onde o corpo é produtor e fonte de conhecimento. Apresentaremos esta metodologia que é tecida por implicações epistemológicas, ativistas, política, ética, em busca de descolonização curricular e do próprio conhecimento, delineada pela escuta sensível, perpassada pelo coletivo, pela memória histórica, pela resistência negra e pela autoformação.
\end{abstract}

Palavras-chave: Metodologia Afrorreferenciada; Odus; Filosofia Africana; Escuta Sensível; Descolonização Curricular

\begin{abstract}
The present article presents the philosophical methodology, which is also content, of the Odus. This is an afro-referenced methodology demarcated by our origin, our ancestry, our paths / experiences. We will nourish here a formative dialogue from cultures, ways of being / being in the world, African and Afro-descendant philosophies and knowledge. It seeks to delineate a diverse, plural form, horizontal, circular perspective that understands universality from a place, from our own ground, where the body is the producer and source of knowledge. We will present this methodology that is woven by epistemological implications, activists, politics, ethics, in search of curricular decolonization and of the knowledge itself, delineated by sensitive listening, perpassed by the collective, by historical memory, by black resistance and self-formation.

Keywords: Afrorreferenced methodology; Odus; African Philosophy; Sensitive Listening;
\end{abstract} Curricular decolonization

\footnotetext{
Esse artigo é oriundo da dissertação de mestrado de Machado. Ver MACHADO, Ancestralidade e Encantamento como inspirações formativas: filosofia africana mediando a história e cultura africana e afrobrasileira, 2014.

* Doutora em Educação-Universidade Federal do Ceará (UFC), Bolsista Capes. E-mail: adilmachado@yahoo.com.br
} 


\section{Adentrando: uma metodologia filosófica afrorreferenciada}

Com o advento da Lei 10.639/2003, que torna obrigatório o ensino de história e cultura africana e afro-brasileira, tornou-se fundante a criação de metodologias que possam delinear, demarcar a implementação de tal lei desde métodos afrorreferenciados, posto que a proposta é um ensino desde nosso próprio lugar de pertencimento, nosso modo de ser, nossos saberes, nossas culturas, nossos corpos, nossas histórias. Assim, essas metodologias são pautadas desde as histórias que nos foram negadas nas escolas e universidades, perpassadas pela oralidade, pela memória, pelos valores que delineiam o cotidiano da população negra diaspórica que forma o Brasil, perpassadas por corpos negados e cheios de potência e resistência.

Dessa forma, dialoga-se desde nossos modos de ser e estar no mundo, desde os (nossos) saberes dos povos africanos que a escravização trouxe para nosso país. Ainda que a colonização tenha nos tornado uma nação marcada por dor, sofrimento, desumanização e negação, ela deixou um legado que segue existindo, re-existindo e fortalecendo um povo que não nasceu em África, mas que tem a África nascida em si, uma África que desenhou, teceu, criou, cria e alimenta o Brasil. Aqui não há, em absoluto, o propósito, ou até mesmo a ideia de romantizar a mestiçagem, longe disso, mas reconhecer que ainda com todos os processos de desumanização oriundos da colonização, da escravização, a cultura africana em terras brasileiras ultrapassa o tempo e os espaços, fundamentando nosso ser, nossa cultura, fortalecendo-se na luta cotidiana por sua existência e re-existência, pois somos um povo demarcado pela ancestralidade e pelo encantamento vindo de África.

Assim, esse artigo propõe um diálogo formativo desde a perspectiva afrorreferenciada, ou seja, as culturas, os modos de ser / estar no mundo, filosofias e saberes africanos e afrodescendentes. Delineando um pensamento plural, diverso, que tem o diálogo entre os saberes como preponderante, desde uma perspectiva horizontal, circular, compreendendo a universalidade desde um lugar, desde nosso próprio chão, abarcando o corpo como produtor e fonte de conhecimento, conhecimentos estes oriundos das relações do cotidiano, das nossas experiências, pois "existir é relacionar-se, e os relacionamentos não se dão no vazio do nada, mas através de corpos que preenchem o corpo do espaço e os escorrer do tempo corporal. Não se prescinde do corpo, nem como

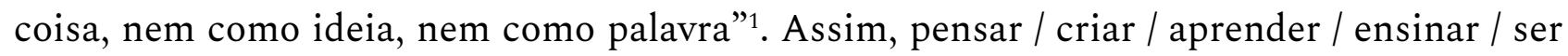
desde referenciais que tem a ancestralidade africana como guia, potencializa nosso estar no mundo, nos encantando, nos implicando com um mundo melhor, mais digno de se viver.

${ }^{1}$ OLIVEIRA, Filosofia da ancestralidade: corpo e mito na filosofia da educação brasileira, p. 107. 
Portanto, esse artigo apresentará a metodologia oriunda da Filosofia Africana delineada pelos Odus. Esses são metodologia e conteúdo demarcados pelos nossos caminhos / experiências / vivências, pois "não separa caminho de metodologia, forma de conteúdo. Elas não são separadas na vida, também não podem ficar separadas na academia"2. Também não dissocia experiência de vivência, de atuação política, ética, social, profissional, assim, trabalha-se desde a compreensão de "formação como ação"3, pois a formação é um "fenômeno que se realiza nos sujeitos concretos, contextualizados, historicizados, política e coletivamente situados". ${ }^{4}$

Odu, que é oriundo do Ifá, é a fonte de inspiração para a criação dessa metodologia, que fora gestada por Eduardo Oliveira ${ }^{5}$ para o ensino de "História e Cultura Africana e Afro-brasileira", desenvolvida, especialmente, para o componente curricular de mesmo nome ofertado no curso de Pedagogia da Faculdade de Educação da Universidade Federal da Bahia, entretanto, tal metodologia pode ser "aplicada" em todos os campos do conhecimento afrorreferenciado, pois Odu é uma metodologia filosófica oriunda das filosofias africana, de seus saberes, valores e tradições. Eduardo Oliveira inspira-se em sua espiritualidade, na sua relação com o Ifá, cultura em que é iniciado. O Ifá é oriundo da Nigéria, é uma cultura pré-colonial que representa um sistema ético africano. Segundo Eduardo Oliveira ${ }^{6}$,

Na religião de matriz africana, pensando ela como um grande fenômeno social, há uma coisa absolutamente importante que é o oráculo. O oráculo é aquilo que faz com que eu possa me comunicar com o Outro perto e com o Outro distante, é a comunicação do humano para com o humano, do humano para com o sagrado e do sagrado para com o humano. É o lugar da fala da sabedoria, ou seja, o oráculo é o lugar que preserva a sabedoria produzida por um grupo. Um oráculo privilegiado por esse sistema se chama IFÁ.

Ronilda Ribeiro7, diz que o Ifá é "Orumilá, o oráculo divino, deus da sabedoria iorubá. Também jogo adivinhatório realizado com ikin ou opelê" (grifo da autora). Para Eduardo Napoleão ${ }^{8}$, o Ifá é o “Oráculo praticado por sacerdotes yourubanos cujo patrono é

\footnotetext{
${ }^{2}$ OLIVEIRA apud MACHADO, Ancestralidade e Encantamento: filosofia africana mediando a história e cultura africana e afro-brasileira, p. 94.

${ }^{3}$ MACEDO, Compreender/mediar a formação: o fundante da educação, 2010.

${ }^{4}$ Ibidem, p. 108.

${ }^{5}$ Professor Adjunto da Faculdade de Educação da Universidade Federal da Bahia (UFBA); Professor Permanente do Doutorado Multi-Institucional e Multidisciplinar em Difusão do Conhecimento (DMMDC) / Salvador. E-mail: afroduda@gmail.com ${ }^{6}$ OLIVEIRA apud MACHADO, Ancestralidade e Encantamento: filosofia africana mediando a história e cultura africana e afro-brasileira, p. 98.

${ }^{7}$ RIBEIRO, Alma Africana no Brasil: Os Iorubás, p. 263.

${ }^{8}$ NAPOLEÃO, Vocabulário Yorùbá, p. 105.
} 
Orunmilá. Compêndio do saber yourubano contendo ensinamentos e textos sobre música, literatura, história, religião, mitologia, ecologia, ciência, filosofia, arte, etc”.

Desse modo, o Opelê-Ifá, que é o colar de Ifá, é utilizado como inspiração metodológica, pois:

é um instrumento (...) para me comunicar com o oráculo, ele é efetivamente a metodologia, o instrumento, aquele que faz a comunicação, aquele que revela a sabedoria produzida pelos antepassados para os viventes de agora e atualiza essa sabedoria na experiência desses viventes de agora? .

Um objetivo fundante do ensino de história e cultura africana e afro-brasileira é o diálogo com as filosofias presentes na sabedoria de nossos antepassados, nas experiências vividas e transmitidas. Sabedorias / Experiências! Sabedorias / Ações! Sabedorias / Modos de Ser - Estar no Mundo!

O oráculo, o opelê-ifá é circular, pois o círculo é "uma estética radical de inclusão (...), todo mundo tá lado a lado com o Outro, com companheirismo, numa relação fraternal (...) e vendo a face do outro. Então, é uma escritura ética, é uma estética de inclusão" ${ }^{10}$. Por isso o círculo é fundante como instrumento metodológico.

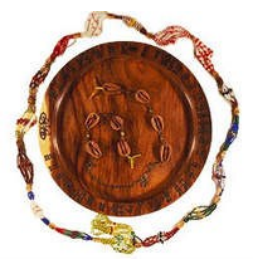

Opelê Ifá - Fonte: Internet

E o oráculo do Opelê-Ifán ${ }^{11}$ :

é composto de oito sementes que são oito caminhos para entendermos o que a gente fez na humanidade desde os primórdios até agora. Só que na cultura Iorubá - Nagô, o Ifá nunca é pensado como um corpo único, sempre é dois, então não existe indivíduo [...], o africano não se pensa como

\footnotetext{
${ }^{9}$ OLIVEIRA apud MACHADO, Ancestralidade e Encantamento: filosofia africana mediando a história e cultura africana e afro-brasileira, p. 99.

${ }^{10}$ Ibidem, p. 99-100.

${ }^{11}$ Segundo Ronilda Ribeiro, “o oráculo sagrado possui 4.096 (16 x 16 x 16) poemas. Com base nesses poemas é feita a interpretação no jogo adivinhatório de Ifá ou de búzios. Por ocasião do processo iniciático o babalaô procura, através do jogo divinatório, tomar conhecimento de qual é o odu de nascimento do iaô que passará a cultuar também o orixá relativo a esse odu, respeitando os ewo (quizilas, restrições) por ele prescritos. O odu de nascimento orienta o iaô quanto ao seu destino, nos mais diversos níveis" (grifo da autora). Ver RIBEIRO, Alma Africana no Brasil: Os Iorubás, 1996.
} 
indivíduo / único, se pensa como comunidade, essa é outra chave de leitura importantíssima, logo o Ifá se pensa sempre como duplo ${ }^{12}$.

A multiplicação é fundamental, o duplo pessoa / comunidade, assim, as sementes do Opelê-Ifá são colocadas lado a lado, ficando quatro sementes de um lado e quatro de outro, ao se abrirem formam oito, que são duplicadas por dois formando dezesseis caminhos e segue multiplicando-se... Assim, enquanto metodologia, a proposta é que os/as educandos/as possam também construir suas próprias metodologias, a construção e a produção é coletiva, é oriunda da experiência vivência de cada um/a, onde todos nossos saberes são valorizados. Portanto, a metodologia dos Odus, inspirada no Ifá, é construída sempre numa perspectiva coletiva e de valorização dos saberes antigos e dos saberes do agora.

ODUS: caminhos / experiências

Os Odus, ou seja, conteúdo e metodologia, apresentam chaves de leituras e de interpretações, instrumentos para produção de outros olhares sobre a história e cultura a africana e afro-brasileira, trazendo sempre os deslocamentos de sentidos, a coletividade, a memória, o corpo e a ludicidade como fios condutores dessa produção. Filosofias fundantes do pensamento africano. Eduardo Oliveira desenvolveu oito Odus, entretanto, iremos trabalhar aqui apenas os cinco primeiros, pois foram estes com os quais se trabalhou, no componente curricular HCAA $^{13}$, no período de 2010 a 2014. Os Odus, os caminhos, que estão em processo, acontecendo, são os seguintes:

1 - Odu de Origem

2 - Odu de Transição

3 - Odu de Desconstrução

4 - Odu de Transformação

5 - Odu de Beleza (Estética / Encantamento)

6 - Odu de Natureza

7 - Odu de Espaço

8 - Odu de Tempo

Agora vamos caminhar com e desde os Odus!

Odu de Origem

\footnotetext{
${ }^{12}$ OLIVEIRA apud MACHADO, Ancestralidade e Encantamento: filosofia africana mediando a história e cultura africana e afro-brasileira, p. 99-100.

${ }^{13}$ Abreviatura de "História e Cultura Africana e Afro-brasileira". Acompanhei o referido componente curricular no período entre 2010 e 2014.
} 
O primeiro Odu a ser apresentado é o de Origem, entretanto, é só didaticamente que se começa por ele, pois origem não é começo, posto que no círculo, no opelê-ifá, podese começar de vários pontos, assim, há mais de uma origem:

não há uma origem única, não tem um dia em que a bondade começou, que a maldade começou, que o homem nasceu, que a história iniciou (...). Isso é sempre dinâmico, (...) a origem é uma questão de escolha, não é uma questão ontológica, ou seja, não é um fato consolidado, é só uma escolha, cada pesquisador, cada pesquisadora, escolhe o seu ponto de partida, porque o ponto de partida não é arbitrário ${ }^{14}$.

Desse modo, é importante compreender que a "origem não se impõe como um dado, a origem é uma construção epistemológica, (...) mental, (...) conceitual” (Idem), é uma escolha e como tal não se dá do nada, é pesquisa científica, e acontece em virtude de nossa liberdade, partindo sempre de um princípio ético. Ética esta que se apresenta como liberdade da pessoa dentro do coletivo, ou seja, é como aquele ditado que diz: "a minha liberdade termina quando a do Outro começa”. Assim:

a origem não dá margem para a arbitrariedade, a origem é fruto de uma livre escolha, portanto, a base de uma escolha é o que caracteriza a humanidade, não é a racionalidade. O que caracteriza o humano é a liberdade e a liberdade não é uma coisa só docinha, gostosa e etc. (...) Por isso a educação é fundamental, por que é a educação que nos dá mais condições de discernimento, de fazermos melhores escolhas sem nenhuma garantia que elas irão dar certo, ninguém pode garantir a vocês do ponto de vista epistemológico que o que ela tá dizendo é garantido, (...) ninguém! Isso eu acho maravilhoso, porque desautoriza as autoridades absolutas e coloca como condição da produção do conhecimento a interação com o outro. O conhecimento não pode ser produzido sozinho, conhecimento é um fenômeno coletivo ${ }^{15}$.

O conhecimento nunca é individual, é coletivo e a liberdade são vestes da criatividade, desse modo:

a base epistemológica da produção do conhecimento não é a lógica, (...) não é o raciocínio causal. A base epistemológica do conhecimento é a criação viva, o universo não está estruturado em torno de matérias antigas, sólidas, o universo está estruturado encima de criação. (...) a matéria é uma ilusão da

\footnotetext{
${ }^{14}$ OLIVEIRA apud MACHADO, Ancestralidade e Encantamento: filosofia africana mediando a história e cultura africana e afro-brasileira, p. 115.

${ }^{15}$ Ibidem, p. 115-116.
} 
compreensão humana e o que a gente tem é um estado pulsante, constante de criação ${ }^{16}$.

A criação é subjetiva e essa subjetividade é quem condiciona a produção de conhecimento e a lógica é o instrumento para organização do conhecimento. Essa subjetividade é responsável, é implicada, portanto, ela se apresenta com a responsabilidade de criar mundos melhores, desde as nossas experiências, vivenciadas em nós mesmos e com o/a/s Outro/a/s. Essa criação oriunda da subjetividade tem origem em nossos processos formativos. É encantamento, implicação e responsabilidade com nosso estar no mundo.

Educar desde uma perspectiva afrorreferenciada, desde as cosmopercepções africanas, é educar pela experiência, pois o conhecimento real, que pode ser efêmero, tem origem em nós, em nosso lugar de pertencimento, nosso chão, nossa cultura e saberes. É o educar o olhar, educar para a sensibilidade, para perceber o Outro como parte de nós mesmos/as, é promover o exercício da nossa capacidade de sentir, de ter a emoção como a base, o sustentáculo para a razão, pois "em formação é preciso entender que a emoção coloca o sujeito em movimento e impulsiona a ação" ${ }^{17}$. Assim, a criação que parte do sentir torna-se base para o conhecimento, para o ser / fazer.

Para Eduardo Oliveira ${ }^{18}$, na educação do olhar há três posições fundamentais: o olhar de longe (ou distanciado), o olhar de perto (ou aproximado) e o olhar do entre-meio ${ }^{19}$. O olhar de longe "tende a privilegiar o conjunto e perder os detalhes. Com isso perde-se o movimento das singularidades e se ganha na percepção da totalidade”, já o olhar de perto "vê fragmentos, mas distancia-se da visão de conjunto" e o olhar do entre-meio é "um híbrido que combina tanto a dinâmica do olhar distanciado quanto do aproximado, ele não substitui, nem supera os outros olhares, pois não se trata nem de negação nem de aprimoramento de outras perspectivas”. Assim, compreende que o olhar do entre-meio é o escolhido para essa construção metodológica, pois é aquele olhar:

que vai de um a outro, tendo como referência sempre o oposto, ou seja, o alheio, o Outro. Assim, quando está sob efeito da vertigem causada pela proximidade (olhar aproximado) terá como referência a mansidão do olhar de totalidade (olhar distanciado) e vice-versa. Ao contemplar o conjunto de uma paisagem terá como referência a singularidade de seus movimentos, pois o olhar entre-meios é uma relação / interação dos extremos. Por isso

\footnotetext{
${ }^{16}$ Ibidem, p. 116.

${ }^{17}$ MACEDO, Compreender/mediar a formação: o fundante da educação, p. 129.

${ }^{18}$ OLIVEIRA, Filosofia da ancestralidade: corpo e mito na filosofia da educação brasileira, p. 238-239.

${ }^{19}$ Segundo o autor, esses olhares caracterizam a percepção da metafísica (olhar de longe), o pensamento pósmoderno (olhar de perto) e a cultura dogon (olhar do entre-meio) que é uma cultura africana que muito influencia a pesquisa que realiza em sua tese. Vide OLIVEIRA, Filosofia da ancestralidade: corpo e mito na filosofia da educação brasileira, p. 237-243.
} 
ele é relativista posto que, ao relacionar-se com os extremos de um oposto a outro, pode redefinir os contextos e suas medidas de grandeza. (...) O olhar entre-meios reconhece que o olhar cria o contexto na mesma medida em que o contexto cria o olhar. Um é corrente para o outro e juntos formam os elos culturais ${ }^{20}$.

Desse modo, no Odu de Origem escolhemos nosso ponto de origem, sabendo-se que essa escolha não é arbitrária e é coletiva, fruto de uma cultura, um chão, de uma ancestralidade que é fonte de pertencimento e que tece esse chão / lugar. Escolhemos nosso lugar de origem, mas como se dá o processo de transição? Nosso próximo Odu poderá nos responder.

\section{Odu de Transição}

Ao encerrarmos, sem encerrar, o Odu de Origem, percebemos que basta apenas escolhermos nossa origem, pois, ainda se apresenta como um ponto, ainda que não seja arbitrário, assim, é imprescindível pensarmos o seu deslocamento, o seu movimento, ou seja, faz-se necessário compreendermos como acontece esta transição ou "como isso se processa na prática, como se ganha forma, corpo ${ }^{21}$ ”. O Odu de Transição tem como conceitos fundamentais o movimento, o deslocamento e o processo, pois:

não basta ter origem, que é uma escolha, que não é um dado imposto, (...) a origem é só origem, é só o primeiro passo, para entender qualquer fenômeno (...) eu preciso entender como isso se modificou, criou movimento, ganhou corpo, como chegou a constituir-se naquilo que eu vejo hoje. Nós não somos os homens primatas que fomos a princípio, nós evoluímos, nós não somos mais aqueles hominídeos, nós somos homens sapiens, sapiens muito desenvolvidos, dizem. Então, eu preciso entender a transição, como a coisa sai do seu estado de origem, do seu estado original (...) para transformar-se naquilo que é hoje, no fenômeno que a gente estuda agora $^{22}$.

É importante destacarmos que isso é válido para qualquer campo do conhecimento, qualquer área. Seguindo essa itinerância, o Odu de Transição apresenta-se como esse processo de compreensão da transição de como algo sai do seu estado original e transforma-se no que vemos, por exemplo: "É entender que têm deslocamento de conceito, de ideia, de pesquisa, que tem além de deslocamento, tenho que acompanhar o

\footnotetext{
${ }^{20}$ OLIVEIRA, Filosofia da ancestralidade: corpo e mito na filosofia da educação brasileira, p. 239.

${ }^{21}$ OLIVEIRA apud MACHADO, Ancestralidade e Encantamento: filosofia africana mediando a história e cultura africana e afro-brasileira, p. 118.

${ }^{22}$ Ibidem.
} 
movimento"23. O movimento é fruto das nossas intenções, dos nossos desejos, dos sopros de vida cotidianos movidos por nossas experiências / vivências, por nossas andanças!

O conhecimento livre e criativo é contínuo, por isso o movimento é sua condição, posto que nada na natureza está parado e não há como pensar, produzir, conhecer, ser desde a perspectiva africana sem que estejamos em relação com a natureza, pois é ela que "nos ajuda a ser o nosso verdadeiro ser" ${ }^{24}$. Porquanto, é fundamental desenvolver, criar epistemologias que acompanhem o movimento próprio da existência, da realidade que vemos, sabendo-se que há diversos modos de se ler as coisas, o mundo (as coisas do mundo), não há uma verdade absoluta, há verdades possíveis, realidades possíveis e diferentes, pois as culturas são diferentes, somos diferentes e essas diferenças são fontes de fortalecimento e crescimento. Eduardo Oliveira ${ }^{25}$ afirma que ainda "perdura o paradigma de que pensar é congelar as coisas, separá-las, é dar respostas definitivas”. Na perspectiva africana "o que não se renova e não se recria continuamente apodrece e morre. É preciso mover-se e se aquecer sempre para manter aceso o pavio da vida” ${ }^{26}$. Portanto:

o objeto de estudo da epistemologia é o processo, é o movimento, não é o resultado, porque nunca tenho resultado final, tenho sempre resultados provisórios e parciais (...). Meu aluno nunca vai estar pronto, eu como professor nunca estarei pronto, é sempre provisória a formação, porque eu sempre vou efetivamente reelaborar, desconstruir, criticar, acrescentar, manter. É dinâmico, não para nunca ${ }^{27}$.

Nesse movimento de existência e re-existência, escolhemos uma origem, transitamos pelos movimentos contínuos e diversos, nos desconstruímos, nos transformamos, pois "conhecer é reter informações, dominar técnicas e reflexões. Sabedoria é mais! Sabedoria é viver o que se conhece" 28 . Então, na busca do viver o que conhecemos, escolhemos / encontramos nossa origem, passamos por um processo de transição e desconstruímos o que nos foi colocado de um modo imposto por uma cultura que se deseja mono (cultura ocidental), transformando-nos e nos encantando, descolonizando e ampliando, trazendo as diversas vozes para a construção, desconstruindo e transformando e não destruindo como é próprio de nossa(s) história(s). Desconstruímos para potencializar a existência, para transformar desde um processo inclusivo, comunitário, circular!

\footnotetext{
${ }^{23}$ Ibidem.

${ }^{24}$ SOMÉ, O Espírito da Intimidade: ensinamentos ancestrais africanos sobre relacionamentos, p. 20.

${ }^{25}$ OLIVEIRA apud MACHADO, Ancestralidade e Encantamento: filosofia africana mediando a história e cultura africana e afro-brasileira, p. 119.

${ }^{26}$ MACHADO, Pele da Cor da Noite, p. 110.

${ }^{27}$ Ibidem.

${ }^{28}$ OLIVEIRA, Filosofia da ancestralidade: corpo e mito na filosofia da educação brasileira, p. 110.
} 


\section{Odu de Desconstrução}

Em nossa caminhada fazemos alguns percursos, passamos por acontecimentos diversos, escolhemos nossa origem, passamos por processos de transição que nos levam a mudanças de paradigmas, porém, é necessário "desconstruir o que tá instituído, mesmo que eu tenha localizado, de maneira livre, o meu ponto de partida, mesmo que eu tenha compreendido o processo e o movimento, eu posso sedimentar, posso ossificar, posso cristalizar esse conhecimento como 'certeza'”29.

Isso implica que é fundante constantemente se fazer crítica, porém uma crítica responsável, construtiva, que nos leve ao descontentamento, ou seja, ao não se acomodar com o que está dado:

com o que já está dito, com o que já está pronto. É a hora de mexer um pouco nas estruturas dos edifícios, (...) é a parte da problematização propriamente dita, é o momento de entender que estudar história e cultura africana não é igual a estudar história ocidental. Isso é óbvio, mas apesar de ser óbvio até hoje não está na academia, por isso a crítica tem que ser cada vez mais radical, não é a crítica pela crítica é a crítica para a raiz, ai está toda a diferença ${ }^{30}$.

É pensar com os pés, pois eles estão sempre plantados no chão, é trazer a cabeça para o chão, pois o chão é a raiz, é a inversão de paradigmas. É mexer nas estruturas, questionar o que está sedimentado e dar sentido desde nosso contexto, os acontecimentos que formam e transformam. Eduardo Oliveira traz a percepção de que, por exemplo, o street dance, o break, o hip hop, etc. tinham muitos movimentos que se davam no chão, "inclusive um dos movimentos mais radicais é rodar sobre a sua própria cabeça com muita velocidade (...). Isso quer dizer muita coisa" ${ }^{31}$. Sabemos que essas danças têm origem na cultura negra, onde "a estética não é uma coisa decorativa, espetacular, ela denuncia uma cultura, apresenta uma cultura, sintetiza e atualiza" ${ }^{32}$. Esses exemplos mostram como é importante levar o nosso cotidiano para sala de aula, para os espaços de ensino aprendizagem, onde os questionamos, proporcionando reflexões desconstrutivas, que nos permitem, por exemplo, sair do ciclo do racismo e ter perspectivas outras dos diferentes modos de ser.

É importante não haver apenas o discurso de diversidade, multirreferencialidade, multiplicidade, diferença, inclusão, multiculturalismo, é importante que isso seja colocado

\footnotetext{
${ }^{29}$ OLIVEIRA apud MACHADO, Ancestralidade e Encantamento: filosofia africana mediando a história e cultura africana e afro-brasileira, p. 120.

${ }^{30}$ Ibidem.

${ }^{31}$ Ibidem.

${ }^{32}$ Ibidem.
} 
em prática, que faça parte da nossa formação, da formação do nosso próprio conhecimento, da nossa cultura, pois essa diversidade, essa multirreferencialidade proporciona valorização e respeito do que é diverso, diferente, valorização e potencialização da diversidade. Onde nossos espaços de ensino - aprendizagem possam ser delineados por um currículo plural, diverso, reflexivo, que tem a vida como fundante para e na sua construção.

Tais reflexões permitem debates pertinentes, abrindo horizontes para que nossos/as estudantes, e até mesmo educadores/as, acreditem que é possível enveredar pelos caminhos que acreditamos, por caminhos outros, culturas outras, ainda que não tenhamos abertura ou que ela seja pequena. "Desconstrução rima com a criação, (...) leva à necessidade de continuar produzindo conhecimento, porque caso contrário posso só repetir conhecimento e repetir não é criar” ${ }^{33}$. Entretanto, há momentos em que a repetição é importante, mas, não podemos ficar sempre na repetição,

é necessário a criação e para isso eu tenho que desconstruir conceitos, metodologias, visões, olhares, imaginários. Desconstruir estruturas sociais, históricas, políticas. Desconstruir é necessário, não é destruir, destruir significa que você vai eliminar, desconstruir significa que você vai decompor para compor novamente, é diferente o sentido ${ }^{34}$.

Esse Odu nos impele a compreender que o conhecimento é contínuo, além de coletivo, é um exercício de crítica radical, ou seja, uma crítica que vai à raiz, questiona toda a estrutura, mas com um sentido de transformação para melhor coletiva, ligada à natureza.

No caminho percorrido entendemos que a origem é uma escolha, assim é fundante refletir o processo, desconstruir as certezas dadas, entretanto, isso não é suficiente para produção de conhecimento, é necessário transformar, compreendendo que "transformar significa que o conhecimento tem que ter implicações práticas, pragmáticas, tem que alterar as relações" ${ }^{35}$. Conhecimento só é válido quando traz transformações, quando altera a realidade, conhecimento como sabedoria, com implicações práticas e que altera as relações.

$\mathrm{Na}$ medida em que o conhecimento não é individual, mas coletivo, dá-se apenas com o encontro. Conhecimento não movimentado não faz sentido, a coletividade está intrínseca ao conhecimento, pois "não basta ter conhecimento cognitivo, é preciso atingir também a sensibilidade e alterar na prática a relação" ${ }^{36}$. Não basta ler um texto, é preciso adentrar suas entranhas, entranha-se pelos sentidos, lê-se com as mãos, com o paladar, o olfato...

\footnotetext{
33 OLIVEIRA apud MACHADO, Ancestralidade e Encantamento: filosofia africana mediando a história e cultura africana e afro-brasileira, p. 121.

${ }^{34}$ Ibidem.

${ }^{35}$ Ibidem.

${ }^{36}$ Ibidem, p. 122.
} 
não se enxerga apenas com os olhos, enxerga-se com todos os sentidos. Comossensações!!! Por isso o educar o olhar!!!

\section{Odu de Transformação}

O Odu de Transformação implica no pensar / fazer desde a ética, no compartilhar, no encontro, o pensar a própria ética, pois “a parte mais importante da ética é a coletividade" 37 . Transformar desde a ética não é qualquer transformação, é uma transformação inclusiva, em comunhão. Desse modo o referido Odu implica em um conhecimento pragmático, ele

causa alterações reais, visíveis, concretas, sólidas. É também a dimensão da ética, que é a dimensão da ação, (...) aqui é o conhecimento já em ação, a atitude ética. E a palavra base dessa ética chama-se responsabilidade, ou seja, essa transformação não é qualquer transformação, (...) eu tenho que pensar as consequências da minha ação (...)! Eu tenho que pensar, refletir, medir as consequências das minhas ações, da minha fala, (...) porque vai ter efeitos práticos na vida de outras pessoas ${ }^{38}$.

Essa ética responsável tem o propósito da manutenção e ampliação da liberdade, onde "uma ação ética é balizada pela responsabilidade com o que você diz e faz. A responsabilidade é o maior princípio da política" 39 , da educação, da vida. Eduardo Oliveira $^{40}$ afirma que "grandes autores do nosso tempo estão falando numa ética da responsabilidade, eu, além, de uma ética da responsabilidade, junto com o pessoal da filosofia da libertação falo de uma ética da libertação, que é uma responsabilidade um pouco mais ampliada”.

Concluímos que não importa apenas o conteúdo, mas o que esse conteúdo pode fazer, as transformações que traz para o cotidiano no qual estamos inseridos/as, o que importa é o que fazemos desse conteúdo, como o potencializamos. Essa é a potência da Lei 10.639 / 11.645, uma ação que reflete nas experiências do cotidiano, implicando no reencontro com nossas origens. O Odu de transformação é delineado pelo Odu de Estética, pelo Encantamento, pois é o transformar-se desde a implicação, a responsabilidade com o estar no mundo!

\section{Odu de Beleza / Estética / Encantamento}

\footnotetext{
${ }^{37}$ OLIVEIRA apud MACHADO, Ancestralidade e Encantamento: filosofia africana mediando a história e cultura africana e afro-brasileira, p. 122.

38 Ibidem.

${ }^{39}$ Ibidem.

${ }^{40}$ Ibidem, p. 213.
} 
Discorrer acerca do Odu de Beleza / Estética / Encantamento é uma tarefa complexa, ainda que este seja um conceito fundante na minha trajetória, não apenas enquanto pesquisadora. Tecer essa teia é intenso, é falar desde a sensibilidade almejando outros modos de concepções da vida, do fazer / produzir/ pensar / criar / ser. É ser desde o coletivo e numa perspectiva de ser de corpo inteiro, onde esse corpo é sagrado, é fundamental. Durante nossa caminhada, geralmente, somos “ensinados/as" que a razão está separada da emoção, acredito que muitos de nós, ou talvez todos/as nós já nos perguntamos, em algum ou em muitos momentos, como isso é possível se tudo está “junto e misturado”. Como separar o que sentimos do que fazemos?

Vanda Machado ${ }^{41}$ nos diz que:

o pensamento africano não separa, não hierarquiza. Corpo, membro, memória, tradição, sentidos, imaginário, símbolos, signos, espiritualidade e as vivências cotidianas, tudo faz parte de uma tradição na sua multidimensionalidade que não se presta a explicação reduzida, a categoria que fragmentam sentido.

Tentaram nos tirar desse lugar, de algum modo o fizeram, pois somos formados/as em outra perspectiva, racionalizada de um jeito que nega o nosso corpo e tenta nos formatar, então, como agir com ética se não somos “ensinados/as” desde a sensibilidade? Se vamos à escola e sentamos em fileiras, um/a atrás do/a outro/a e não olhamos no olho? Se a educação escolar aparece como um lugar onde temos que guardar informações (não, necessariamente, compreendê-las, mas, principalmente, armazená-las) que nem sempre diz quem somos, qual a nossa história, qual a nossa origem. Se somos orientados/as a concluir uma graduação, depois um mestrado, depois um doutorado, depois, depois... sempre numa perspectiva de juntarmos bens materiais, melhor salário, onde a qualidade de vida está relacionada a um status social?

Assim, o Odu de Beleza acaba por ter a responsabilidade de implantar uma dimensão filosófica em nosso estar no mundo, em relação aos Odus apresentados anteriormente. O Odu do encantamento "produz os sentidos da vida, é esse odu que produz o mundo, (...) constrói o mundo" ${ }^{42}$.

Vivemos no mundo da complexidade, "pois quanto mais complexidade, mais a minha liberdade aumenta" ${ }^{43}$ e é dentro da complexidade que fazemos escolhas, desse modo, "quanto mais complexo for o meu olhar, maior a minha possibilidade de escolha" ${ }^{44}$,

\footnotetext{
${ }^{41}$ MACHADO, Pele da Cor da Noite, p. 52.

${ }^{42}$ OLIVEIRA apud MACHADO, Ancestralidade e Encantamento: filosofia africana mediando a história e cultura africana e afro-brasileira, p. 124.

${ }^{43}$ Ibidem, p. 125.

${ }^{44}$ Ibidem.
} 
quanto mais complexa a realidade, maior deve ser meu critério, o discernimento para essas escolhas, assim "a gente pode educar o nosso olhar para as complexidades, porque o mundo é complexo, não adianta olhar o mundo reduzindo a certo e errado" 45 . Educar o olhar para a sensibilidade é caminhar por princípios formativos outros, princípios que tem a ética do corpo, do desejo pelo Outro/a e o respeito à diversidade como fios condutores para o próprio existir.

A morte foi um dos temas que teceram o Odu de Estética / Beleza / Encantamento, delineado por diversas músicas, onde dialogamos sobre rituais de morte em algumas culturas, especialmente na africana, pois "a crença na imortalidade do homem explica, em grande parte, a grande importância que a morte e os ritos funerários têm na cosmovisão de mundo africana ${ }^{46}$. Sabemos que:

a morte abrange as esferas mais importantes da vida africana, pois abarca a concepção de homem, a necessidade das restituições dos papéis sociais mais importantes, como chefes de família ou governantes políticos. Isto porque, uma vez ocorrido o evento da morte o equilíbrio da comunidade está posto em questão, pois as personagens que morreram sintetizam as ações históricas do grupo. É neste momento que os ritos funerários ganham grande importância, pois eles são capazes de reorganizar rapidamente as comunidades restabelecendo o equilíbrio social ${ }^{47}$.

Eduardo Oliveira ${ }^{48}$ considera que a "cultura é a reposta ao problema da morte", se quisermos conhecer bem uma cultura deveríamos procurar "saber seus rituais fúnebres". Nessa perspectiva a morte aparece não como lamento, mas como reorganização do meio onde se vive, como um renascimento, pois ela é a condição para o nascimento. Nesse momento a música "Drão” de Gilberto Gil chega para dialogar conosco. É importante demarcarmos que a metodologia dos Odus, perpassada pela nossa memória histórica, pelo nosso cotidiano, é tecida pelas artes que nos tecem, assim, a música, a dança, o desenho, enfim, a arte como um modo geral é instrumento metodológico, pois Odus vem dos sentidos, do sentir.

Drão ${ }^{49}$

\footnotetext{
${ }^{45}$ Ibidem.

${ }^{46}$ OLIVEIRA, Cosmovisão africana no Brasil: elementos para uma filosofia afrodescendente, p. 56.

${ }^{47}$ Ibidem.

${ }^{48}$ OLIVEIRA apud MACHADO, Ancestralidade e Encantamento: filosofia africana mediando a história e cultura africana e afro-brasileira, p. 125.

${ }^{49}$ Essa música data de 1982, fora feita quando da separação de Gilberto Gil com sua 3ª esposa, Sandra, com a qual vivera 17 anos. Fonte: http://www.overmundo.com.br/banco/drao-historia-que-a-musica-de-gilberto-gilconta
} 
"Drão,

o amor da gente é como um grão,

uma semente de ilusão,

tem que morrer pra germinar,

plantar nalgum lugar,

ressuscitar no chão

nossa semeadura!

Quem poderá fazer

aquele amor morrer?

Nossa caminha dura!

Dura caminhada

pela estrada escura.

Drão,

não pense na separação,

não despedace o coração,

o verdadeiro amor é vão,

estende-se, infinito,

imenso monolito,

nossa arquitetura.

Quem poderá fazer

aquele amor morrer?

Nossa caminha dura!

Cama de tatame

pela vida afora...

Drão,

os meninos são todos sãos,

os pecados são todos meus,

Deus sabe a minha confissão,

não há o que perdoar

por isso mesmo é que há

de haver mais compaixão!

Quem poderá fazer

aquele amor morrer,

se o amor é como um grão:

morre, nasce trigo,

vive, e morre pão!

Drão” 
Após ouvirmos a música, destacamos a seguinte parte: "o amor é como um grão: morre, nasce trigo, vive e morre pão!” Após muitas reflexões coletiva fortalecemos a concepção de que “a condição para o nascimento é a morte e que um tema está absolutamente relacionado ao outro" ${ }^{50}$. Do ponto de vista psicológico é o que fazemos continuamente, pois:

sofremos muitas mortes e temos necessidade de renascer de novo. A gente se perpetua, enquanto espécie, no círculo morte e nascimento (...). A cada dia que se vive a gente fica mais morto, é o paradoxo do viver, e ao mesmo tempo, quanto mais morto, nesse sentido aqui que a gente está falando, que estou falando, mais consciente de que estou vivo estarei. ${ }^{51}$

Seguindo a sensibilidade imposta pelos acontecimentos cotidianos ${ }^{52}$, da produção em diálogo, somos apresentados/as a mais uma música, considerada com uma perspectiva mais ocidental, em contraponto às reflexões anteriores, escutemos:

\section{Canto Para a Minha Morte ${ }^{53}$}

Eu sei que determinada rua que eu já passei

Não tornará a ouvir o som dos meus passos.

Tem uma revista que eu guardo há muitos anos

E que nunca mais eu vou abrir.

Cada vez que eu me despeço de uma pessoa

Pode ser que essa pessoa esteja me vendo pela última vez

A morte, surda, caminha ao meu lado

E eu não sei em que esquina ela vai me beijar

Com que rosto ela virá?

Será que ela vai deixar eu acabar o que eu tenho que fazer?

Ou será que ela vai me pegar no meio do copo de uísque?

Na música que eu deixei para compor amanhã?

Será que ela vai esperar eu apagar o cigarro no cinzeiro?

\footnotetext{
${ }^{50}$ OLIVEIRA apud MACHADO, Ancestralidade e Encantamento: filosofia africana mediando a história e cultura africana e afro-brasileira, p. 126.

${ }^{51}$ Ibidem, p. 127.

${ }^{52}$ Nessa metodologia os acontecimentos cotidianos são sempre respeitados, privilegiados. As singularidades de cada um/a em um constante diálogo com o conhecer, seria compreender que "dependendo da coragem de compreensão com que nos lançamos a investigar e buscar compreender o que 'descobrimos do real', podemos estender o alcance de nosso olhar, de nosso coração (um excelente instrumento de interpretação da vida e de nós mesmos) e de nossa mente”. Ver BRANDÃO, O que é educação, p. 44.

${ }^{53}$ Essa música faz parte do quinto álbum solo de Raul Seixas (cantor e compositor baiano), lançado em 1976 , intitulado "Há dez mil anos atrás".
} 
Virá antes de eu encontrar a mulher, a mulher que me foi destinada,

E que está em algum lugar me esperando

Embora eu ainda não a conheça?

Vou te encontrar vestida de cetim,

Pois em qualquer lugar esperas só por mim

E no teu beijo provar o gosto estranho

Que eu quero e não desejo, mas tenho que encontrar

Vem, mas demore a chegar.

Eu te detesto e amo morte, morte, morte

Que talvez seja o segredo desta vida

Morte, morte, morte que talvez seja o segredo desta vida

Qual será a forma da minha morte?

Uma das tantas coisas que eu não escolhi na vida.

Existem tantas... Um acidente de carro.

O coração que se recusa abater no próximo minuto,

A anestesia mal aplicada,

A vida mal vivida, a ferida mal curada, a dor já envelhecida

O câncer já espalhado e ainda escondido, ou até, quem sabe,

Um escorregão idiota, num dia de sol, a cabeça no meio-fio...

Oh morte, tu que és tão forte,

Que matas o gato, o rato e o homem.

Vista-se com a tua mais bela roupa quando vieres me buscar

Que meu corpo seja cremado e que minhas cinzas alimentem a erva

E que a erva alimente outro homem como eu

Porque eu continuarei neste homem,

Nos meus filhos, na palavra rude

Que eu disse para alguém que não gostava

E até no uísque que eu não terminei de beber aquela noite...

Vou te encontrar vestida de cetim,

Pois em qualquer lugar esperas só por mim

E no teu beijo provar o gosto estranho que eu quero e não desejo, mas tenho que encontrar

Vem, mas demore a chegar.

Eu te detesto e amo morte, morte, morte

Que talvez seja o segredo desta vida

Morte, morte, morte que talvez seja o segredo desta vida 
A reflexão acerca dos sentidos dessa música acaba por delinear nosso pensamento para "tornar o mistério palatável dentro do limite do viver" ${ }^{54}$, ou seja, compreender que a ancestralidade nos forma, acessando aquilo que não podemos identificar. Desse modo, não seria acessar o mistério, mas produzir sentido desde e para esse mistério, pois quando produzimos sentidos "se morde a ponta do mistério" ${ }^{55}$, ou seja, o mistério é a possibilidade da existência, é o que movimenta, é movimento!

Nossas reflexões chegam à religião, pois "toda vez que se fala de nascimento, de morte e nascimento, é quase impossível você não falar de religião. A religião é uma resposta cultural à morte e ao nascimento, (...) não há religião que não trate desse tema como prioridade" ${ }^{56}$. É, então, mais uma perspectiva para compreendermos o mistério da vida, as perguntas que nos seguem em nosso cotidiano: por que nascemos, para quê, para onde vamos, qual a nossa “missão" nesse mundo ${ }^{57}$. Novamente uma música vem dialogar conosco, mais uma vez Raul Seixas provoca reflexões com “Ave Maria da Rua”.

\section{Ave Maria da Rua}

No lixo dos quintais

Na mesa do café

No amor dos carnavais

Na mão, no pé, oh

Tu estás, tu estás

No tapa e no perdão

No ódio e na oração

Teu nome é Yemanjah (Yemanjah)

E é Virgem Maria

É Glória e é Cecília

Na noite fria

Oh, minha mãe

\footnotetext{
${ }^{54}$ OLIVEIRA apud MACHADO, Ancestralidade e Encantamento: filosofia africana mediando a história e cultura africana e afro-brasileira, p. 128.

${ }^{55}$ Ibidem.

${ }^{56}$ Ibidem.

${ }^{57}$ Lembro-me de quando criança seguir anos buscando entender por que havia nascido, pra quê, qual era minha “missão" neste mundo. No início da adolescência compreendi que nasci para melhorar-me como pessoa. Hoje, pensando desde a cosmopercepção na qual me reconheço, refletindo desde a ancestralidade africana, compreendo que se melhorar como pessoa só é possível quando encontramos a teia do nosso ser e compreendemos que ao nos tornarmos pessoas "melhores”, tornamo-nos mais éticos e vamos ao encontro com o/a Outro/a, entendendo esse/a Outro/a como algo que me completa e que é completado por mim, sempre numa perspectiva do coletivo.

58 Também faz parte do álbum “Há dez mil anos atrás” de Raul Seixas.
} 
Minha filha tu és qualquer mulher

Mulher em qualquer dia

Bastou o teu olhar (Teu olhar)

Pra me calar a voz

De onde está você

Rogai por nós

Ooooh, Ooooh!

Minha mãe, minha mãe

Me ensina a segurar

A barra de te amar

Não estou cantando só

Cantamos todos nós

Mas, cada um nasceu

Com a sua voz,

Ooooh, Ooooh!

Pra dizer, pra falar

De forma diferente

O que todo mundo sente

Segure a minha mão

Quando ela fraquejar

E não deixe a solidão

Me assustar

Ooooh, Ooooh!

Minha mãe, nossa mãe

e mata minha fome

Nas letras do teu nome

Ooooh, Ooooh!

Minha mãe, nossa mãe

E mata minha fome

Nas letras do teu nome

Ooooh, Ooooh!

minha mãe, nossa mãe

E mata minha fome

Na glória do teu nome.

Após ouvirmos a música algumas vezes, houve uma breve explanação do seu tempo histórico (ditadura militar), em seguida refletimos a questão de gênero, a associação da mulher com a divindade criadora, na cultura africana, enquanto o homem no ocidente é considerado o criador. Para a cultura africana a união dos gêneros é necessária para a construção e manutenção do mundo. Assim, in-concluimos o Odu de Encantamento com o 
mito de "Oxum na organização do mundo", que traz a importância fundante da mulher na construção do mundo. Quem nos conta tal mito é Vanda Machado e Carlos Petrovich ${ }^{59}$ :

\section{Oxum na organização do Mundo}

Era uma vez, no princípio do mundo, Olodumaré mandou todos os orixás para organizarem a terra. Os homens faziam reuniões e mais reuniões. Somente os homens, as mulheres não eram convidadas. Aliás as mulheres foram proibidas de participar da organização do mundo. Deste modo nos dias e horas marcadas, os homens deixavam em casa as suas mulheres e saiam para tomar as providências indicadas por Olodumaré.

As mulheres não gostaram de ficar de lado. Contrariadas foram conversar com Oxum.

Oxum era conhecida como uma Iyalodé.

Iyalodé é um título da pessoa mais importante entre as mulheres do lugar.

$\mathrm{Na}$ verdade, parece que os homens tinham esquecido do poder de Oxum sobre a água doce.

E sem a água doce, com certeza, a vida na terra seria impossível.

Oxum já estava aborrecida com esta desconsideração dos homens. Afinal ela não poderia de forma alguma ficar longe das deliberações para o crescimento das coisas da terra.

Ela sabia de tudo que estava acontecendo.

Era preciso compreender que todos são importantes para a construção do mundo.

Procurado por suas companheiras, conversavam durante muito tempo e por fim a Iyalodé comunicou: - De hoje em diante, vamos mostrar o nosso protesto para os homens.

Vamos chamar atenção, porque somos todos responsáveis pela construção do mundo.

Enquanto não formos consideradas, vamos parar o mundo!

- Parar o mundo? O que significa isto? Perguntaram as mulheres curiosas.

- De hoje em diante, falou Oxum, até que os homens venham conversar conosco, estamos todas impedidas de parir. Também as árvores não vão mais dar frutos, nem as plantas vão florescer, nem crescer. Isto foi dito e isto aconteceu.

Aquela foi uma reunião muito forte. A decisão foi acatada por todas as mulheres.

E os resultados foram imediatos. Os planos que os homens faziam, começaram a se perder sem nenhum efeito.

Desesperados, os homens se dirigiram a Olodumaré e explicaram como as coisas iam mal sobre a terra. As decisões tomadas nas assembleias não davam certo de forma nenhuma.

${ }^{59}$ PETROVICH; MACHADO. Irê Ayó: Mitos Afro-brasileiros, p. 69-71. 
Olodumaré ficou surpreso com as más notícias.

Depois de meditar por alguns instantes perguntou:

- Vocês estão fazendo tudo como eu mandei? Oxum está participando destas reuniões?

Os homens responderam: - Veja senhor, estamos fazendo tudo "direitinho" como o senhor mandou. Agora, este negócio de mulher participando de nossas reuniões...

Isto ai, a gente não fez assim não.

Coisa de homem, tem que ser separado de coisa de mulher.

Olodumaré falou forte:

- Não é possível. Oxum é o orixá da fecundidade. É quem faz desenvolver tudo que é criado.

Sem Oxum o que é criado não tem como progredir.

Por exemplo, vocês já viram alguma coisa plantada crescer sem água doce?

Os homens voltaram correndo para a terra e cuidaram logo de corrigir aquela grande falha.

Quando chegaram à casa de Oxum, ela já esperava na porta, fazendo jeito de quem não sabia o que estava acontecendo. Aí os homens foram chegando e dizendo:

- Agô nilê! (Com licença).

\section{In-conclusões caminhantes}

Compreendo não ser possível ensinar sobre história e cultura africana e afrobrasileira sem pensar uma educação para as relações étnico-raciais, sem voltar-se para comunidade como um todo, sem a escuta sensível, sem pensar o coletivo. O que não é válido apenas para o ensino de história e cultura africana e afro-brasileira, pois não é suficiente ter conhecimento cognitivo se não mudarmos nossas práticas, se não trabalharmos esse conhecimento, assim, essa é uma perspectiva válida em todos os campos do conhecimento, da vida. Experiência / vivência / aprendência...

A metodologia dos Odus é tecida por memórias históricas, pois "valorizar a memória e a resistência negra contra as hegemonias é um processo decolonial e ressignificante, que fortalece o combate contra o preconceito e a discriminação racial que afetam a nossa sociedade, possibilitando a mudança do cenário de desigualdade vivida no Brasil”60. Assim, também é perpassada pela autoformação na busca de uma sociedade mais justa, democrática, antirracista, contra o patriarcalismo, contra toda e qualquer forma de opressão. Metodologia tecida por implicações epistemológicas, ativistas, política, ética, em busca da descolonização curricular, do conhecimento e de nossos próprios corpos.

${ }^{60}$ CORREA. Pequena África e os cotidianos da resistência: o cinema negro como possibilidades para e Lei 10.639/03, p. 127. 
Ancestralidade tecendo o presente para um futuro livre, liberdade demarcada pela conquista de todos os direitos, bem-viver!

Assim, in-concluo esse artigo convidando a cada leitor e a cada leitora a desenvolver suas próprias metodologias, os Odus estão ai para serem recriados, tecidos desde o contexto social, histórico de cada um, de cada uma. Tecidos por nossas próprias histórias, por nossas escrevivências, como diria Conceição Evaristo, delineado por educadores e educadoras que se compreendem como aprendizes contínuos, e também enxergam seus educandos e suas educandas como construtores de todo e qualquer processo de aprendizagem. Odus é uma metodologia, que também é conteúdo, da escuta sensível, da potencialização da vida! Que caminhando possamos construir outros mundos melhores, mundos encantados, fortalecidos, potencializados por nossa ancestralidade, afrorreferenciado nossos modos de ser / fazer. Filosofia(s) Africana(s) como poéticas de sentidos, do viver!

“Antes de morder veja com atenção se é pedra ou se é pão”. Mãe Stella de Oxóssi

\section{Referências}

BRANDÃO, Carlos Rodrigues. O que é educação. São Paulo: Brasiliense, 2007.

CORREA, Marco Aurélio. Pequena África e os cotidianos da resistência: o cinema negro como possibilidades para e Lei 10.639/03. Revista da $A B P N$, v. 10, Ed. Especial-Caderno Temático: História e Cultura Africana e Afro-brasileira - lei 10.639/03 na escola, p.109-134, maio-2018.

MACEDO, Roberto Sidnei. Compreender/mediar a formação: o fundante da educação. Brasília: Liber Livro Editora, 2010.

MACHADO, Adilbênia Freire. Ancestralidade e Encantamento: filosofia africana mediando a história e cultura africana e afro-brasileira. Dissertação (mestrado) - Universidade Federal da Bahia. Faculdade de Educação, Salvador, 2014.

MACHADO, Vanda. Pele da Cor da Noite. Salvador: EDUFBA, 2013.

NAPOLEÃO, Eduardo. Vocabulário Yorùbá. Rio de Janeiro: Pallas, 2011.

OLIVEIRA, Eduardo David de. Filosofia da ancestralidade: corpo e mito na filosofia da educação brasileira. Curitiba: Editora Gráfica Popular, 2007.

OLIVEIRA, E. D. de. Cosmovisão africana no Brasil: elementos para uma filosofia afrodescendente. Curitiba: Editora Gráfica Popular, 2006.

PETROVICH, Carlos; MACHADO, Vanda. Irê Ayó: Mitos Afro-brasileiros. Salvador: EDUFBA, 2004. 
RIBEIRO, Ronilda Iyakemi. Alma Africana no Brasil: Os Iorubás. São Paulo: Editora Oduduwa, 1996.

SOMÉ, Sobonfu. O Espírito da Intimidade: ensinamentos ancestrais africanos sobre relacionamentos. SP: Odysseus Editora, 2003. 